\title{
Antimicrobial activity of ethanolic and aqueous extracts of medicinally used tree ferns Alsophila cuspidata and Cyathea microdonta
}

\author{
Charlie Longtine ${ }^{1} \&$ Adrian Tejedor ${ }^{2}$ \\ ${ }^{1}$ The University of North Carolina at Chapel Hill \\ ${ }^{2}$ The School for Field Studies
}

\author{
Correspondencia \\ A. Tejedor \\ e-mail: adriantejedor@gmail.com \\ Recibido: 6 junio 2017 \\ Aceptado: 29 agosto 2017 \\ Publicado on-line: diciembre 2017
}

\begin{abstract}
Resumen
Actividad antimicrobiana de extractos en etanol y agua de los helechos arborescentes usados medicinalmente Alsophila cuspidata y Cyathea microdonta

Las plantas medicinales son componentes importantes de farmacologías tradicionales y fuentes de compuestos antimicrobianos que pueden combatir patógenos resistentes a antibióticos comerciales. Este estudio examinó la actividad antimicrobiana de extractos en etanol y agua de dos helechos aborescentes Neotropicales usados medicinalmente (Alsophila cuspidata y Cyathea microdonta) frente a bacterias grampositivas y gramnegativas usando el método de difusión de Kirby-Bauer. La mayor actividad antimicrobiana se observó en extractos en etanol y frente a bacterias grampositivas. No hubo diferencias entre especies de helechos o entre extractos obtenidos de frondes, peciolos, o troncos. Estos resultados sugieren que el uso tradicional del mucílago de helechos arborecentes como agente tópico en cortes y lesiones de leishmaniasis pueden reducir el riesgo de infecciones con bacterias cutáneas como Staphylococcus aureus y que las Cyatheaceae Neotropicales son una fuente potencial de compuestos antimicrobianos novedosos.
\end{abstract}

Palabras clave: Helechos arborescentes, medicina tradicional, Amazonia peruana, Kirby-Bauer.

\begin{abstract}
Medicinal plants are important components of traditional medicine and sources of novel antimicrobial compounds against drug resistance pathogen strains. This study tested the antimicrobial activity of ethanolic and aqueous extracts of medicinally used Neotropical tree ferns Cyathea microdonta and Alsophila cuspidata against gram positive bacteria and gram negative bacteria using the Kirby-Bauer disc diffusion method. Highest antimicrobial activity was observed in ethanolic extracts, and extracts were more active against gram positive bacteria than gram negative bacteria. No difference was observed in antimicrobial activity between species or between extracts made from the leaves, stipe, or caudex. These results suggest that the traditional use of tree fern mucilage as a topical agent for cuts and leishmaniasis lesions may reduce risk of secondary infection with skin bacteria such as Staphylococcus aureus, and that Neotropical Cyatheaceae are a potential source of novel antimicrobial compounds.
\end{abstract}

Key words: Tree ferns, traditional medicine, Peruvian amazon, Kirby-Bauer.

\section{Introduction}

Medicinal plants have a long and diverse history of use throughout the world, and currently one- quarter to one-half of all pharmaceuticals dispensed have higher-plant origins (Cowan 1999). However, very few plant derivatives are used as antimicrobials in western medicine, as we have relied on fungal 
and bacterial sources for these compounds since the advent of antibiotics, despite the abundant antimicrobials present in plants as defense compounds against phytopathogens (Gonzáles-Lamothe et al. 2009). Plant materials constitute a major part of traditional medicinal responses to microbial infection, and have been identified as a major resource of antimicrobial compounds as multiple drug resistant strains of pathogens to current antimicrobials increasingly emerge (Gurib-Fakin 2006, Dimayuga and Garcia, 1991). Extracts of plants used in traditional medicine have been shown to have antimicrobial effects against human pathogens such as gram positive bacteria (Zakaria et al 2007), Pseudomonas aeruginosa (Bjarnsholt et al. 2005), and Leishmania amazonensis (Soares et al. 2009).

Tree ferns in the family Cyatheaceae, commonly known as sano sano in southern Peru, are traditionally used in Cusco, Puno, and Madre de Dios, Peru as medicinal plants against cutaneous leishmaniasis, bruises, and wounds by applying mucilage directly on the affected area (authors' pers. observ.). The potential medical uses of compounds derived from old world tree ferns have been suggested by recent studies of methanolic extracts from leaves. Alsophila gigantea Wall. ex Hook. (treated as Cyathea) a common tree fern in South India, for example, has shown antiinflammatory activity (Madhukiran et al. 2011), hepatoprotective effects (Madhukiran et al. 2012), and free radical scavenging activity (Madhukiran 2011). Also, old world tree ferns have been shown to contain a large number of compounds with potential medicinal uses. Flavonoids, steroids, and saponins have been isolated from both the leaves and caudex of $A$. gigantea (treated as Cyathea) and Sphaeropteris brunoniana (Wall. ex Hook.) R.M. Tryon (treated as Cyathea, Talukdar et al. 2010), and these categories of compounds have antimicrobial potential (Cowan 1999). A recent assessment of fern antimicrobial activity in India including the tree ferns Alsophila nilgirensis R.M. Tryon (treated as Cyathea) and Sphaeropteris crinita R.M. Tryon (treated as Cyathea) showed inhibitory effects toward Pseudomonas aureus, Klebsiella pneumonia, Aspergillus niger, and Fusarium sp., but no activity against the gram positive Streptococcus species tested (Johnson et al. 2012). This study only used ethanol as a solvent of extraction however, which has been reported to extract fewer antimicrobial compounds than other solvents (Nostro et al. 2000, Eloff 1998, Ahmad et al. 1998).

To date, although used as staple medicine in rural areas, Neotropical species of Cyatheaceae have not been formally tested for antimicrobial properties. The present study, therefore, aims to investigate the antimicrobial effects of both ethanolic and aqueous extracts of leaves, stipe, and trunks from Alsophila cuspidata (Kunze) D.S. Conant and Cyathea microdonta (Desv.) Domin, two tree ferns used in traditional medicine in the Peruvian amazon.

\section{Objectives}

To determine whether extracts from two species of Neotropical tree ferns have antimicrobial activity

\section{Methods}

Study site: The study was performed at the Villa Carmen Biological Station (VC, -12.895, -71.404) of the Amazon Conservation Association (ACA), in the locality of Pilcopata, district of Kosñipata, province of Paucartambo, Cusco, Peru. VC is located on the Amazonian foothills of the Andes, at $540 \mathrm{~m}$, in the buffer zone of Manu National Park, and is surrounded by secondary premontane rainforest, with an annual precipitation of $3000-5000 \mathrm{~mm}$.

Species selection: Fronds, stipe, and trunks were cut from healthy, disease free tree ferns from the species Cyathea microdonta and Alsophila cuspidata. These two species were chosen because they produce multiple trunks from a single rhizome and do not die when one trunk is cut. They are also among the species used indistinctly by the local population as a source of mucilage for treating wounds.

Extract preparation: The stipe and caudex were cut into $0.5 \mathrm{~cm}^{3}$ pieces and dried at $50^{\circ} \mathrm{C}$ for 2 hours. Fronds were similarly dried. $50 \mathrm{~g}$ of stipe and caudex and $5 \mathrm{~g}$ of fronds were extracted in $100 \mathrm{~mL}$ of both $96 \%$ ethanol and boiled water for 12 hours. Three plant parts from both species were extracted in both ethanol and water for a total of 12 extracts. Extracts were filtered and concentrated by evaporation at $50^{\circ} \mathrm{C}$ to $20 \mathrm{~mL}$. Antibiotic controls were prepared using $200 \mu \mathrm{g}$ Ampicillin per milliliter water for gram negative bacteria and $200 \mu \mathrm{g}$ Ciprofloxacin per milliliter water for gram positive bacteria.

Bacterial culture: Single colony gram positive bacteria isolates were obtained from skin swabs streaked on Staphylococcus gelatin media (Maitland and Martyn, 1948) and incubated in nutrient broth for 12 hours at approximately $37^{\circ} \mathrm{C}$. Single colony gram negative bacteria isolates 
were obtained from fecal swabs streaked on Mueller-Hinton agar (Merck) prepared according to manufacturer's instructions and incubated in nutrient broth for 12 hours at approximately $37^{\circ} \mathrm{C}$. Bacteria were identified using colony morphology (Chiller et al. 2001).

Kirby-Bauer Disc Diffusion Method: Antibacterial tests were performed using the KirbyBauer method with modification (Bauer et al., 1966). Sterile plates containing $4 \mathrm{~mm}$ depth of Mueller-Hinton agar were prepared and inoculated with $0.5 \mathrm{~mL}$ culture of gram positive bacteria or gram negative bacteria and let dry for 5 minutes. Filter paper discs (6mm in diameter) were impregnated with approximately $50 \mu \mathrm{L}$ of extract, dried for 5 minutes, and placed on the inoculated plates alongside the positive antibiotic control. The plates were inverted and incubated at approximately $37^{\circ} \mathrm{C}$ for 12 hours. Antimicrobial activity was indicated by presence of a zone of inhibition of bacterial growth around the disc. The distance from the edge of the disc to the outer ring of the zone of inhibition was measured. The tests were repeated 4 times for each extract using both gram positive bacteria and gram negative bacteria.

Statistical Analysis: All statistical analyses were performed using PAST (Hammer and Harper, 2006). The Wilcoxon signed rank test was used to compare extractants and species, and a KruskalWallis was used to compare leaf, stipe, and caudex extracts.

\section{Results}

Both C. microdonta and A. cuspidata showed antibiotic activity (figure 1). The mean zone of inhibition for all extracts against gram positive bacteria and gram negative bacteria is given in figure 1. Ethanolic extractions had significantly larger zones of inhibition than aqueous extracts against gram positive bacteria but not gram negative bacteria (Wilcoxon test, exact $p$ (same) $=$ 0.007227 and exact $p$ (same) $=0.21212$ ). Overall, there was no significant difference in antibacterial
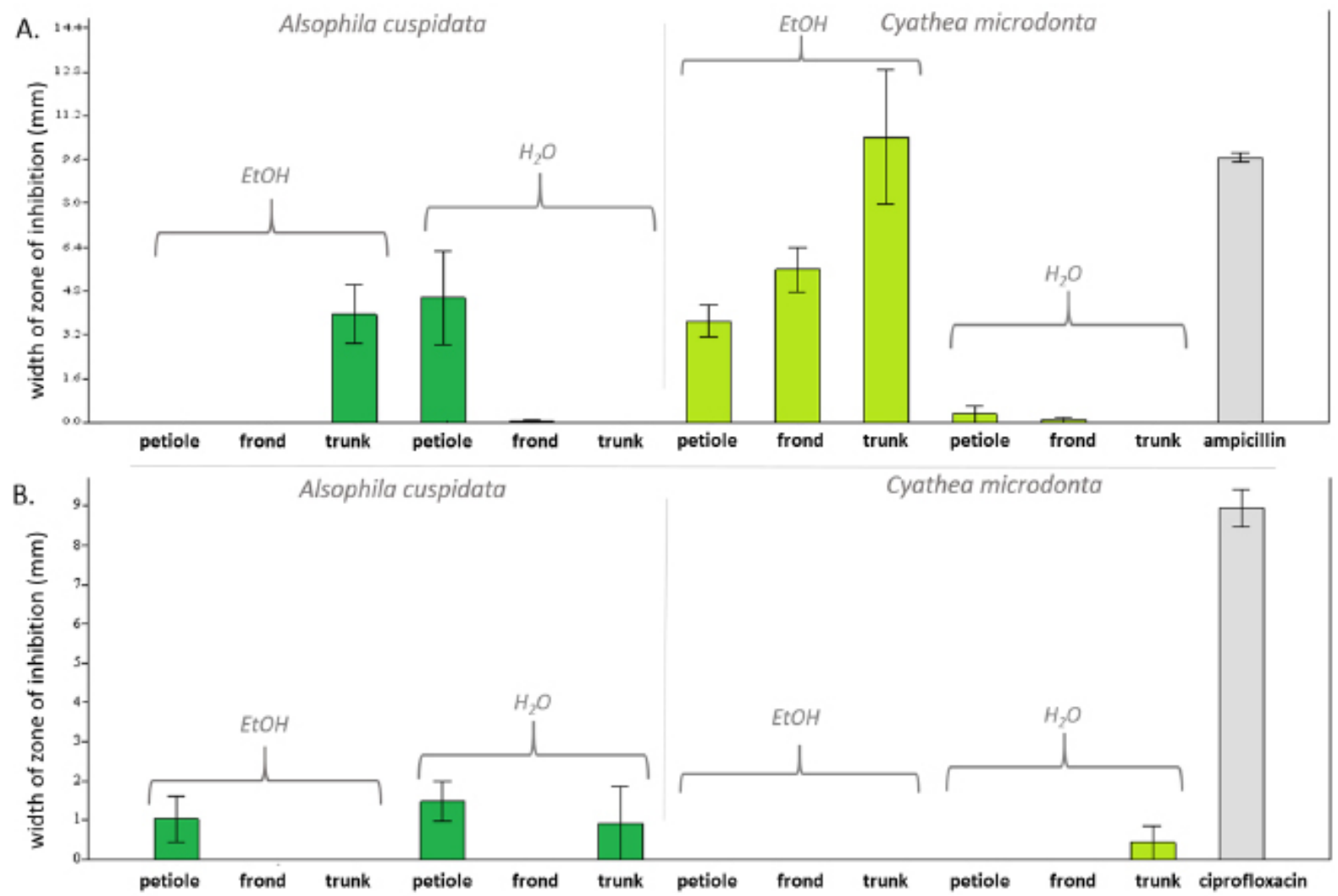

Figure 1: Width of the zone of inhibition for 12 tree fern extracts plus Ampicillin against gram positive bacteria (A) and gram negative bacteria (B). Figura 1: Ancho de la zona de inhibicion de 12 extractos de helechos arborescentes mas ampicilina frente a bacterias grampostitivas $(\boldsymbol{A})$ y gramnegativas (B). 
activity between C. microdonta and A. cuspidata against gram positive bacteria or gram negative bacteria (Wilcoxon test, exact $p$ (same) $=0.056892$ and exact $p$ (same) $=0.054264)$. No significant difference was found between extracts from different plant parts against gram positive bacteria and gram negative bacteria (Kruskal-Wallis). Extracts showed significantly more activity against gram positive gram positive bacteria than gram negative gram negative bacteria (Wilcoxon test, exact $p($ same $)=0.00014)$.

\section{Discussion}

The present study confirmed the presence of antimicrobial compounds in Cyathea microdonta and Alsophila cuspidata with activity against potential human pathogens. Although ethanol is not viewed as an efficient extractant of antimicrobial compounds, the ethanolic extracts tested here showed more antimicrobial activity than aqueous extracts. This study underlines the importance of extractant choice in studies of plant antimicrobial activity. Cyatheaceae species should thus be further studied with additional extracts.

The presence of antimicrobial compounds throughout the plants in the leaves, stipe, and caudex supports a previous study that found compounds with potential antimicrobial activity in both the leaves and the caudex (Talukdar et al., 2010). Furthermore, the similarity in antimicrobial activity between $C$. microdonta and $A$. cuspidata suggests the possibility that antimicrobial compounds are widespread throughout Neotropical Cyatheaceae, although further description of the specific compounds present in each species is crucial to understanding whether these compounds are a shared ancestral trait. Further study on the differences or similarity between the genera Alsophila and Cyathea could elucidate evolutionary adaptations to pathogens within this family.

Traditional medicinal use of tree fern mucilage is generally topical, for example on cuts or leishmaniasis lesions. Coinfection of leishmaniasis lesions with gram positive bacteria enhances the severity of early lesions (Potter et al., 1983), so application of tree fern mucilage may be beneficial in preventing coinfection and thus reducing lesion severity. Ziaie and Sadeghian (2008) found that $20.7 \%$ of patients with cutaneous leishmaniasis had secondary bacterial infections, and of these, $69.4 \%$ were gram positive bacteria, $23.1 \%$ were coagulase negative Staphylococcus, and $3.9 \%$ were gram negative bacteria. Since the caudex extracts from both species, which contained the mucilage, showed inhibitory activity against gram positive bacteria, this study validates the traditional topical use of the mucilage on cutaneous leishmaniasis lesions in combination with oral or intravenous anti-leishmanial therapy.

The greater activity against gram positive bacteria than gram negative bacteria is presumably due to the impermeable outer membrane of gram negative bacteria, which prevents exposure of the peptidoglycan cell wall, the internal membrane, and the cytoplasm. The higher susceptibility of gram positive bacteria to plant extracts is consistent with previous findings (Lai et al., 2009; Johnson et al., 2012; Ahmad et al., 1998).

The zones of inhibition around discs impregnated with extracts were not as clear as the zones around antibiotic control discs, and bacterial colonies were frequently in the inhibition zone of extracts. This may be due to the presence of carbohydrates which promote bacterial growth in the extracts due to the extraction process. Future studies should reduce the carbohydrate content in extracts, which is possible by extracting with a Soxhlet extractor. (Nostro et al., 2000). Additionally, because of limitations on the equipment available for this study, the exact concentrations of crude extract used is uncertain. Further studies on antimicrobial properties of tree ferns could obtain more rigorous, quantitative data by quantifying extract concentration and determining the minimum inhibitory concentration of each of the extracts.

Tree ferns have potential both as a topical agent to prevent secondary infection of skin lesions and as a source for new antimicrobial compounds. Further studies should test tree ferns with different extractants, determine the minimum inhibitory concentration, and attempt to isolate specific compounds and elucidate the mode of action of antimicrobial activity.

\section{Conclusions}

We found that extracts of the Neotropical tree ferns Alsophila cuspidata and Cyathea microdonta have antimicrobial activity against gram positive bacteria. There were no significant differences in effect between the two species or among different parts of the plants. Our results indicate that the tree fern mucilage, which is frequently used as a traditional rural remedy in southern Peru on wounds and leishmaniasis lesions, should help control infections from cutaneous bacteria.

\section{Acknowledgements}

We thank the Amazon Conservation Association for hosting us during our study. Villa Carmen Biological 
Station staff, Leonidas Huacac y Adrian Quispe, graciously assisted us in the field and helped with the collection of samples. We are grateful to the School for Field Studies for support and especially to Nicole Wischlinski and Rachel Johnson for help with logistics.

\section{References}

Ahmad, I., Mehmood, Z. \& Mohammad, F. (1998). Screening of some Indian medicinal plants for their antimicrobial properties. Journal of Ethnopharmacology 6(2), 183-193.

Bauer, A.W., Kirby, W.M., Sherris, J.C., \& Turck, M. (1966). Antibiotic susceptibility testing by a standardized single disk method. American Journal of Clinical Pathology 45(4), 493-496.

Bjarnsholt, T., Jensen, P.O., Rasmussen, T.B., Christophersen, L., Calum, H., Hentzer, M., Hougen, H.P., Rygaard, J., Moser, C., Eberl, L., Hoiby, N., \& Givskov, M. (2005). Garlic blocks quorum sensing and promotes rapid clearing of pulmonary Pseudomonas aeruginosa infections. Microbiology. 151(12), 38733880

Chiller, K., Selkin, B., \& Murakawa, G.J. (2001). Skin Microflora and Bacterial Infections of the Skin. Journal of Investigative Dermatology Symposium Proceedings. 6(3), 170-174.

Cowan, M.M. (1999). Plant products as antimicrobial agents. Clinical Microbiology Reviews. 12(4), 564-582

Dimayuga, R.E., \& Garcia, S.K. (1991. Antimicrobial screening of medicinal plants from Baja California Sur. Mexico. Journal of Ethnopharmacology. 31(2), 181192

González-Lamothe, R., Mitchell, G., Gattuso, M., Diarra, M.S., Malouin, F., \& Bouarab, K. (2009). Plant antimicrobial agents and their effects on plant and human pathogens. International Journal of Molecular Sciences. 10(8), 3400-3419.

Eloff, J.N. (1998). Which extractant should be used for the screening and isolation of antimicrobial components from plants? Journal of Ethnopharmacology 60(1), 1-8.

Gurib-Fakin, A. (2009). Medicinal plants: Traditions of yesterday and drugs of tomorrow. Molecular Aspects of Medicine. 27(2006), 1-93.

Hammer, Ø. \& Harper, D.A.T. (2006). Paleontological Data Analysis. Blackwell.

Johnson, M., P., Raja, D., Irudayaraj, V., \& Janakiraman, N. (2012). Antimicrobial efficacy of selected ferns of Western Ghats, South India. International Journal of Current Pharmaceutical Research. 4(2), 58-60

Lai, H.Y., Lim, Y.Y., \& Tan, S.P. (2009). Antioxidative, tyrosinase inhibiting and antibacterial activities of leaf extracts from medicinal ferns. Bioscience, Biotechnology, and Biochemistry. 73(6), 1362-1366.

Madhu Kiran, P. (2011). In vitro evaluation for free radical scavenging activity of methanolic leaf extract of Cyathea gigantea (Wall. Ex. Hook). International Journal of Pharmaceutical Research and Development. 3(2), 95-96.

Madhu Kiran, P., \& Ganga Rao, B. (2011). Antiinflammatory activity of methanolic leaf extract of Cyathea gigantea. (Wall. Ex. Hook.). International Journal of Pharmaceutical Research and Development. 3(3), 3-9.

Madhu Kiran, P., Vijaya Raju, A., \& Ganga Rao, B. (2012). Investigation of hepatoprotective activity of Cyathea gigantea (Wall. Ex. Hook.) leaves against paracetamol-induced hepatotoxicity in rats. Asian Pacific Journal of Tropical Biomedicine. 2(5), 352-356.

Maitland, H.B., \& Martyn, G. (1948). A selective medium for isolation of gram positive bacteria based on the differential inhibiting effects of increased concentrations of sodium chloride. Journal of Pathological Bacteriology. 60(4), 553-561.

Nostro, A., Germano, M.P., D’Angelo, V., Marino, A., \& Cannatelli, M.A. (2000). Extraction methods and bioautography for evaluation of medicinal plant antimicrobial activity. Letters in Applied Microbiology. 30(5), 379-384.

Potter, M.E., Chapman, W.L. JR., Hanson, W.L., \& Blue, J.L. (1983). Leishmania braziliensis: effects of bacteria (gram positive bacteria and Pasteurella multocida) on the developing cutaneous leishmaniasis lesion in the golden hamster. Experimental Parasitology. 56(1), 107-118.

Soares, D.C., Andrade, A.L.S., Delorenzi, J.C., Silva, J.R.A., Freire-de-Lima, L., Falcao, C.A.B., Pinto, A.C., Rossi-Bergmann, B., \& Saraiva, E.M. (2010). Leishmanicidal activity of Himatanthus sucuuba latex against Leishmania amazonensis. Parasitology International. 59(2), 173-177.

Talukdar, A.D., Choudhury, M.D., Chakraborty, M., \& Dutty, B.K. (2010). Phytochemical screening and TLC profiling of plant extracts of Cyathea gigantea (Wall. Ex. Hook.) Haltt. and Cyathea brunoniana. Wall. Ex. Hook. (Cl. \& Bak.). Assam University Journal of Science \& Technology. 5(1), 70-74.

Zakaria, Z., Sreenivasan, S., \& Mohamad, M. (2007). Antimicrobial activity of Piper ribesoides root extract against gram positive bacteria. Journal of Applied Biological Sciences. 1(3), 87-90.

Ziaie, H., \& Sadeghian, G. (2008). Isolation of bacteria causing secondary bacterial infection in the lesions of cutaneous leishmaniasis. Indian Journal of Dermatology. 53(3),129-131. 
